\title{
Methylation in HT22 cells and primary hippocampal neurons with and without isoflurane exposure
}

\author{
Stefanie Klenke*, Christian Specking, Maike Stegen, Andrea Engler and Jürgen Peters
}

\begin{abstract}
Background: Epigenetic modulation may play a role in anesthesia related phenotypes, such as cognitive impairment or memory loss, especially with exposure to anesthetics in the vulnerable phase of brain development. While isoflurane anesthesia can evoke neuroinflammation and neuroapoptosis in young animals, we investigated in a permanent hippocampal cell line (HT22) and in primary hippocampal neurons in an a priori in vitro analysis, whether isoflurane exposure 1) evokes DNA methylation changes in genes involved in apoptosis and inflammation, and 2) results observed in a permanent hippocampal cell line are comparable to primary hippocampal neurons. In case of methylation changes in specific genes, (3) mRNA analysis was performed to assess possible effects on gene expression.
\end{abstract}

Methods: HT22 cells and primary mouse hippocampal neurons were exposed to 3\% isoflurane for $4 \mathrm{~h}$ and DNA (each 6 single experiments) and RNA (3 single independent experiments) were extracted. Methylation analysis (EpiTect Methyl II PCR Array Systems, Qiagen) included the methylation status of 66 genes involved in apoptosis, cytokine production, inflammatory response, and autoimmunity. Quantitative Real-Time PCR was performed using the Quantitect SYBR Green Kit on a Step One Plus.

Results: Methylation status was markedly different between immortalized HT22 cells and cultured primary hippocampal neurons without isoflurane exposure. Of 66 genes investigated, 29 were methylated to a significantly greater degree in HT22 cells compared to primary hippocampal neurons. In cultured primary hippocampal neurons, in contrast, there was a greater methylation in several genes involved in inflammation, accompanied with significant downregulation of C-X-C motif chemokine 12 with isoflurane exposure $(p=0.023)$.

Conclusions: We demonstrate marked differences in gene methylation between HT22 cells and cultured primary hippocampal neurons without isoflurane exposure, with a greater methylation of several genes involved in inflammation upon isoflurane exposure and significant downregulation of Cxc/12 mRNA expression in primary hippocampal neurons. Accordingly, further investigations of anesthesia related DNA methylation should be performed with special consideration being given to the choice of cells targeted for such investigations.

Keywords: Anesthetics, Volatile; Isoflurane, Cxcl12, Inflammation, Epigenetic changes, Gene expression, Methylation

* Correspondence: Stefanie.Klenke@uk-essen.de

Klinik für Anästhesiologie \& Intensivmedizin, Universität Duisburg-Essen and

Universitätsklinikum Essen, Hufelandstr. 55, D-45122 Essen, Germany

(c) The Author(s). 2020, corrected publication 2020. Open Access This article is licensed under a Creative Commons Attribution 4.0 International License, which permits use, sharing, adaptation, distribution and reproduction in any medium or format, as long as you give appropriate credit to the original author(s) and the source, provide a link to the Creative Commons licence, and indicate if changes were made. The images or other third party material in this article are included in the article's Creative Commons licence, unless indicated otherwise in a credit line to the material. If material is not included in the article's Creative Commons licence and your intended use is not permitted by statutory regulation or exceeds the permitted use, you will need to obtain permission directly from the copyright holder. To view a copy of this licence, visit http://creativecommons.org/ licenses/by/4.0/. The Creative Commons Public Domain Dedication waiver (http://creativecommons.org/publicdomain/zero/1. 0/) applies to the data made available in this article, unless otherwise stated in a credit line to the data. 


\section{Background}

Environmental influences are translated by epigenetic mechanisms into expression changes of target genes, which may have significant roles in brain development. Administration of anesthetics also represents an environmental influence which can induce epigenetic changes, especially when exposed in the vulnerable phase of brain development. As an example, administration of ethanol, one of the oldest anesthetics known, during critical stages of brain development, results in significant chromatin remodelling $[1,2]$ in the promoters of several genes leading to long-term cognitive impairments, such as the brain-derived neurotrophic factor (BDNF) and c-Fos genes [1, 3]. Furthermore, general anesthesia can induce histone modification, resulting in suppression of, e.g., mouse Per2 expression in the suprachiasmatic nucleus [4] and c-Fos and BDNF histones within the immature rat hippocampus [5]. A further study revealed increased occupancy and methylation levels at the promoter region of the BDNF accompanied by suppressed BDNF expression and subsequent memory loss [6].

Together, these studies provide hints that epigenetic modulation may play a role in anesthesia related phenotypes. While isoflurane anesthesia can evoke neuroinflammation [7] and neuroapoptosis [8-10] in animal experiments, we investigated in this a priori in vitro analysis, whether isoflurane causes DNA methylation changes in an array of genes involved in apoptosis, cytokine production, and inflammatory response. We also assessed whether results obtained in the permanent hippocampal cell line HT22 are comparable with those in primary cultured hippocampal neurons. If results were comparable, further research, of cause, would be much easier than obtaining and maintaining in culture postnatal primary hippocampal neurons.

Therefore, we measured and compared methylation of an array of genes of HT22 cells and primary hippocampal neurons without and after isoflurane exposure. In case of changes in methylation of specific genes, mRNA analysis was performed to assess possible effects on gene expression.

\section{Methods}

\section{Cell lines}

HT22 is an immortalized mouse hippocampal cell line, which is a sub-line derived from parent HT4 cells that were originally immortalized from cultures of primary mouse hippocampal neurons [1]. The HT22 cells were a generous gift from the Salk Institute (La Jolla, CA, USA). HT22 cells were routinely maintained in Dulbecco's modified Eagle's medium (DMEM) supplemented with $10 \%$ fetal bovine serum, and in a 5\% CO2 atmosphere at $37^{\circ} \mathrm{C}$.
Primary mouse hippocampal neurons were purchased from Lonza (M-HI-401, LOT numbers: 030807, 301,006, and 240,807, Basel, Switzerland). Mouse hippocampal neurons were isolated from E16-17, CD-1 mice which had been killed by decapitation, and then cryopreserved at primary passage. They stain positive for PGP and Tuj1 and test negative for mycoplasma. Preparation of medium, coating of cell culture plates, thawing of cells / initiation of culture process, and maintenance of the cell culture was performed according to the manufacturer's instructions. On day 1 of each experiment, thawing of cells and initiation of the culture process was started. Cells were seeded for experiments on day 4, 5, or 6 and underwent isoflurane or control exposures on the following day (day 5,6, or 7). The morphology of cultured cells was assessed once daily by microscopy.

\section{Cell exposures}

For isoflurane exposure, HT22 cells or primary hippocampal neurons were transferred into a BillupsRothenburg chamber (MIC-101, Billups-Rothenburg, Del Mar, CA) [11]. An in-line calibrated anesthetic agent Vaporizer (Dräger, Lübeck, Germany) was used to deliver isoflurane to the gas phase of the culture wells. Control air (5\% CO2, 21\% O2, balance nitrogen) (Air Liquide, Düsseldorf, Germany) and 3\% isoflurane were delivered into the chamber with $5 \mathrm{l} / \mathrm{min}$ over $20 \mathrm{~min}$. Effluent isoflurane, and carbon dioxide concentrations were monitored during flushing the chamber via a sampling port connected to an anesthetic agent analyzer (DrägerVamos, Lübeck, Germany). The chamber was then placed immediately into an incubator and remained there for $4 \mathrm{~h}$. Isoflurane concentrations (3\%) were again checked after 30, 90, and $180 \mathrm{~min}$ after exposure while flushing the chamber for $5 \mathrm{~min}$. Control experiments were performed in the same manner, except that no isoflurane was added.

\section{Experimental protocol}

Three hundred thousand HT22 cells were seeded in 6well plates and underwent isoflurane exposure or control experiments without isoflurane. The experiments were repeated 6 times.

Primary hippocampal neurons were cultivated according to the manufacturer's instructions. On culture days 4 , 5, and 6200.000 cells were seeded on a 24-well plate and underwent isoflurane or control exposures the following day (day 5, 6 or 7). For methylation analysis, this experiment was performed twice, resulting in 6 single experiments. Therefore, in the methylation analysis of primary hippocampal neurons, 2 experiments performed on day 5, 2 experiments performed on day 6, and 2 experiments performed on day 7 were included. For analysis of mRNA expression in primary hippocampal 
neurons, 3 independent experiments, in which cells underwent isoflurane or control exposures at day 5,6 or 7 were included.

Immediately after $4 \mathrm{~h}$ of isoflurane exposure, DNA and RNA were extracted from the respective cells.

\section{Methylation analysis}

DNA was extracted with the DNeasy Blood \& Tissue Kits (Qiagen, Hilden, Germany) and DNA concentration was measured by a spectrometer (Eppendorf, Hamburg, Germany).

Methylation of genes was analyzed with EpiTect Methyl II PCR Array Systems (Qiagen, Hilden, Germany), which examines the methylation status across a CpG-rich sequence in gene promoters. The method is based on the detection of remaining input DNA after cleavage with a methylation-sensitive and/or a methylation-dependent restriction enzyme (EpiTect Methyl II DNA Restriction Kit, Qiagen, Hilden, Germany). These enzymes digest unmethylated and methylated DNA, respectively. Following digestion, the remaining DNA is quantified by realtime PCR $\left(\mathrm{RT}^{2} \mathrm{SYBR}^{\circ}\right.$ Green qPCR Mastermix, Qiagen, Hilden, Germany) in each individual enzyme reaction using primers that flank a promoter (gene) region of interest. We analyzed the DNA methylation status of 22 genes of the pathways focused EpiTect Methyl II PCR Array Systems (Qiagen, Hilden, Germany), i.e., apoptosis (EAMM-121Z, Table 1), cytokine production (EAMM$541 \mathrm{Z}$, Table 2), and inflammatory response and autoimmunity (EAMM-521Z, Table 3). The relative fractions of methylated and unmethylated DNA are subsequently determined by comparing the amount in each digest with that of a mock (no enzymes added) digest using the $\Delta \mathrm{Ct}$ method as recommended by the manufactor (Qiagen, Hilden, Germany).

\section{Quantitative real-time PCR}

RNA was extracted with peqGOLD MircoSpin Total RNA Kits (Peqlab Biotechnology, Erlangen, Germany) at the indicated time point. RNA concentration was measured by a spectrometer (Eppendorf, Hamburg, Germany). First-strand cDNA was synthesized from $1 \mu \mathrm{g}$ of total RNA with oligodT primers (Roche, Mannheim, Germany) by using Superscript II reverse transcriptase, as recommended by the supplier (Invitrogen, Carlsbad, CA). Relative quantification of mRNA expression was carried out by using primers for those genes whose methylation level showed a difference greater than $20 \%$ among in the primary hippocampal neurons with and without isoflurane exposure (Cxcl12, Cxcl14, Gata3, Il11, Il13, and Il4ra,; for primer details see supplementary Table 1 , for gene details see Table 3), taking several considerations of reference gene selection into account [11]. Contamination with genomic DNA was circumvented by DNase treatment of RNA and by using RNA as template.
The PCR reaction mix was prepared using the Quantitect SYBR Green Kit (Qiagen, Hilden, Germany) following the manufacturer's instructions. PCR was performed in the Step One Plus (Applied Biosystems, Foster City, USA). RealTime PCR experiments were performed three times.

\section{Statistical analysis}

Data are presented as means \pm standard deviation (SD). Data were analyzed using Graph Pad Prism 6 (Graph Pad Software, La Jolla, CA). Methylation analysis was done according to the manufacturer's instructions. A change in methylation of $>20 \%$ was considered as significant, according to the instructions of the manufacturer and comparable to other studies using the EpiTect Methyl II PCR Array System $[12,13]$. Here, DNA methylation was compared between apoptosis-related genes in pleomorphic adenomas of the salivary glands [13], respectively in genes involved in inflammation and autoimmunity in inflammatory bowel disease [12]. mRNA expression was done in genes with significant methylation changes, according to references [12, 13], and analyzed with an unpaired t-test. This An a priori alpha error $\mathrm{p}$ of less than 0.05 was considered to indicate statistical significance.

\section{Results \\ Methylation of HT22 cells and primary hippocampal cells without isoflurane exposure}

In a first step, we measured methylation of genes in HT22 and in primary hippocampal neurons in control experiments without exposure to isoflurane (Fig. 1a-c). Interestingly, the methylation status between the immortalized cell line HT22 and the primary hippocampal neuron cultures was markedly different. In general, methylation of genes in HT22 cells was greater than in the primary cells. Eight of 22 genes of the apoptosis array (Bid, Bik, Cideb, Dapk1, Hrk, Ltbr, Tnfrsf21, and Tnfrsf25) were significantly greater $(>20 \%)$ methylated in HT22 cells compared to primary hippocampal neurons (Fig. 1a). For example, methylation of Bik was $99.4 \%$ in HT22 cells, whereas it was $0.2 \%$ in primary hippocampal neurons (Fig. 1A). In the cytokine array, genes Bcl10, Bcl3, Cd114, Furin, Gata3, Irf1, Ltb, Myd88, and Stat $5 a$ showed $>20 \%$ methylation changes in the HT22 cells compared to the primary hippocampal neurons (e.g. Ltb: $99.6 \%$ vs. 0.4\%) (Fig. 1b). Most differences were found in genes of the inflammatory array. Here, 12 of 22 genes (Cx3cl1, Cxcl12, Cxcl14, Gata3, Il10ra, Il11, Il13, Il13ra1, Il17ra, Il7, Ltb, and Tgfb1) were significantly greater (>20\%) methylated in HT22 cells compared to primary hippocampal neurons (Fig. 1c). Methylation of Cxcl12 was $99.7 \%$ in HT22 cells, whereas it was $0.6 \%$ in primary hippocampal neurons (Fig. 1c). Only one gene (Il18) was nearly completely methylated in the primary neurons (>99.8\%). 
Table 1 Apoptosis Array

\begin{tabular}{|c|c|c|c|}
\hline Gene & Description & Gene ID & Function \\
\hline Apaf1 & apoptotic peptidase activating factor 1 & 11,783 & Caspase \& Regulator \\
\hline Bad & BCL2-associated agonist of cell death & 12,015 & $\begin{array}{l}\text { Induction of Apoptosis } \\
\text { Positive Regulator of Apoptosis }\end{array}$ \\
\hline Bax & BCL2-associated $X$ protein & 12,028 & $\begin{array}{l}\text { Induction of Apoptosis } \\
\text { Anti-Apoptosis } \\
\text { Positive Regulator of Apoptosis } \\
\text { Caspase \& Regulator }\end{array}$ \\
\hline $\mathrm{BCl} 2 \mathrm{|11}$ & BCL2-like 11 & 12,125 & $\begin{array}{l}\text { Induction of Apoptosis } \\
\text { Positive Regulator of Apoptosis }\end{array}$ \\
\hline Bclaf1 & BCL2-associated transcription factor 1 & 72,567 & $\begin{array}{l}\text { Induction of Apoptosis } \\
\text { Positive Regulator of Apoptosis }\end{array}$ \\
\hline Bid & $\mathrm{BH} 3$ interacting domain death agonist & 12,122 & $\begin{array}{l}\text { Induction of Apoptosis } \\
\text { Positive Regulator of Apoptosis }\end{array}$ \\
\hline Bik & BCL2-interacting killer & 12,124 & $\begin{array}{l}\text { Induction of Apoptosis } \\
\text { Positive Regulator of Apoptosis }\end{array}$ \\
\hline Birc2 & baculoviral IAP repeat-containing 2 & 11,797 & Negative Regulator of Apoptosis \\
\hline Bnip3l & BCL2/adenovirus E1B interacting protein 3-like & 12,177 & $\begin{array}{l}\text { Induction of Apoptosis } \\
\text { Anti-Apoptosis } \\
\text { Negative Regulator of Apoptosis } \\
\text { Positive Regulator of Apoptosis }\end{array}$ \\
\hline Casp3 & caspase 3 & 12,367 & $\begin{array}{l}\text { Induction of Apoptosis } \\
\text { Negative Regulator of Apoptosis } \\
\text { Caspase \& Regulator }\end{array}$ \\
\hline Casp9 & caspase 9 & 12,371 & Caspase \& Regulator \\
\hline Cideb & cell death-inducing DNA fragmentation factor, alpha subunit-like effector B & 12,684 & $\begin{array}{l}\text { Induction of Apoptosis } \\
\text { Positive Regulator of Apoptosis }\end{array}$ \\
\hline Cradd & CASP2 and RIPK1 domain containing adaptor with death domain & 12,905 & $\begin{array}{l}\text { Induction of Apoptosis } \\
\text { Positive Regulator of Apoptosis } \\
\text { Caspase \& Regulator }\end{array}$ \\
\hline Dapk1 & death associated protein kinase 1 & 69,635 & $\begin{array}{l}\text { Induction of Apoptosis } \\
\text { Anti-Apoptosis } \\
\text { Negative Regulator of Apoptosis }\end{array}$ \\
\hline Dffa & DNA fragmentation factor, alpha subunit & 13,347 & $\begin{array}{l}\text { Induction of Apoptosis } \\
\text { Negative Regulator of Apoptosis }\end{array}$ \\
\hline Fadd & Fas (TNFRSF6)-associated via death domain & 14,082 & $\begin{array}{l}\text { Induction of Apoptosis } \\
\text { Positive Regulator of Apoptosis }\end{array}$ \\
\hline Gadd45a & growth arrest and DNA-damage-inducible 45 alpha & 13,197 & Induction of Apoptosis \\
\hline Hrk & harakiri, BCL2 interacting protein & 12,123 & $\begin{array}{l}\text { Induction of Apoptosis } \\
\text { Anti-Apoptosis } \\
\text { Positive Regulator of Apoptosis }\end{array}$ \\
\hline Ltbr & lymphotoxin B receptor & 17,000 & Induction of Apoptosis \\
\hline Tnfrsf21 & tumor necrosis factor receptor superfamily, member 21 & 94,185 & Induction of Apoptosis \\
\hline Tnfrsf25 (Dr3) & tumor necrosis factor receptor superfamily, member 25 & 85,030 & $\begin{array}{l}\text { Induction of Apoptosis } \\
\text { Positive Regulator of Apoptosis }\end{array}$ \\
\hline Trp53 & transformation related protein 53 & 22,059 & $\begin{array}{l}\text { Induction of Apoptosis } \\
\text { Negative Regulator of Apoptosis } \\
\text { Positive Regulator of Apoptosis } \\
\text { Caspase \& Regulator }\end{array}$ \\
\hline
\end{tabular}

Influence on isoflurane exposure on methylation in primary hippocampal cells

We measured whether isoflurane exposure alters methylation of genes in primary hippocampal neurons (Fig. 2). However, no changes were seen for genes of the apoptosis array (Fig. 2a) and the cytokine array (Fig. 2b).
There was a greater than $20 \%$ methylation change for several genes in the inflammatory array after isoflurane exposure: Cxcl12, Cxcl14, Gata3, Il11, Il13, and Il4ra (Fig. 2c). Methylation of Cxcl12 was $0.6 \%$ without, but $27.5 \%$ with isoflurane exposure. For all genes, variation between the single experiments was seen (Fig. 2c). In 
Table 2 Cytokine Array

\begin{tabular}{|c|c|c|c|}
\hline Gene & Description & Gene ID & Function \\
\hline BCl10 & B cell leukemia/lymphoma 10 & 12,042 & $\begin{array}{l}\text { T \& B Cell Function Regulator } \\
\text { Transcriptional Regulator } \\
\text { Cytokine Production Signaling Molecule }\end{array}$ \\
\hline $\mathrm{BCl} 3$ & B cell leukemia/lymphoma 3 & 12,051 & $\begin{array}{l}\text { T \& B Cell Function Regulator } \\
\text { Transcriptional \& Translational Regulator } \\
\text { Cytokine Production Signaling Molecule }\end{array}$ \\
\hline Cd14 & CD14 antigen & 12,475 & Environment \& Intracellular Stimuli Response \\
\hline Furin & furin & 18,550 & T Cell Function Regulator \\
\hline Gata3 & GATA binding protein 3 & 14,462 & $\begin{array}{l}\text { Transcriptional Regulator } \\
\text { Environment \& Intracellular Stimuli Response }\end{array}$ \\
\hline Hmox1 & heme oxygenase 1 & 15,368 & $\begin{array}{l}\text { T Cell Function Regulator } \\
\text { Environment \& Intracellular Stimuli Response } \\
\text { Cytokine Production Signaling Molecule }\end{array}$ \\
\hline lgf2bp2 & insulin-like growth factor 2 mRNA binding protein 2 & 319,765 & Translational Regulator \\
\hline ॥18 & interleukin 18 & 16,173 & T Cell Function Regulator \\
\hline$\| 9 r$ & interleukin 9 receptor & 16,199 & Environment \& Intracellular Stimuli Response \\
\hline Inha & inhibin alpha & 16,322 & B Cell Function Regulator \\
\hline Irf1 & interferon regulatory factor 1 & 16,362 & Transcriptional Regulator \\
\hline Ltb & lymphotoxin B & 16,994 & $\begin{array}{l}\text { Environment \& Intracellular Stimuli Response } \\
\text { Cytokine Production Signaling Molecule }\end{array}$ \\
\hline Malt1 & MALT1 paracaspase & 24,354 & $\begin{array}{l}\text { T Cell Function Regulator } \\
\text { Environment \& Intracellular Stimuli Response } \\
\text { Cytokine Production Signaling Molecule }\end{array}$ \\
\hline Map 3 k7 & mitogen-activated protein kinase kinase kinase 7 & 26,409 & $\begin{array}{l}\text { T Cell Function Regulator } \\
\text { Cytokine Production Signaling Molecule }\end{array}$ \\
\hline Myd88 & myeloid differentiation primary response gene 88 & 17,874 & $\begin{array}{l}\text { Environment \& Intracellular Stimuli Response } \\
\text { Cytokine Production Signaling Molecule }\end{array}$ \\
\hline Prkca & protein kinase C, alpha & 18,750 & Environment \& Intracellular Stimuli Responses \\
\hline Smad3 & SMAD family member 3 & 17,127 & $\begin{array}{l}\text { Transcriptional Regulator } \\
\text { Environment \& Intracellular Stimuli Response } \\
\text { Cytokine Production Signaling Molecule }\end{array}$ \\
\hline Smad4 & SMAD family member 4 & 17,128 & Transcriptional Regulator \\
\hline Sod1 & superoxide dismutase 1 , soluble & 20,655 & $\begin{array}{l}\text { T Cell Function Regulator } \\
\text { Environment \& Intracellular Stimuli Response } \\
\text { Cytokine Production Signaling Molecule }\end{array}$ \\
\hline Stat5a & signal transducer and activator of transcription $5 \mathrm{~A}$ & 20,850 & $\begin{array}{l}\text { T \& B Cell Function Regulator } \\
\text { Transcriptional Regulator } \\
\text { Environment \& Intracellular Stimuli Response } \\
\text { Cytokine Production Signaling Molecule }\end{array}$ \\
\hline Traf2 & TNF receptor-associated factor 2 & 22,030 & $\begin{array}{l}\text { T Cell Function Regulator } \\
\text { Cytokine Production Signaling Molecule }\end{array}$ \\
\hline Traf6 & TNF receptor-associated factor 6 & 22,034 & $\begin{array}{l}\text { T Cell Function Regulator } \\
\text { Cytokine Production Signaling Molecule }\end{array}$ \\
\hline
\end{tabular}

HT22 cells, neither methylation of the genes in the apoptosis array (A), nor those in the cytokine (B) or in the inflammatory arrays $(C)$ was altered by isoflurane (Supplementary Fig. 1).

\section{mRNA expression analysis of inflammatory genes in primary cells}

To elucidate whether greater methylation of several genes in the inflammatory array with isoflurane exposure altered mRNA expression of these genes, RT primer were designed for genes, in which methylation was > 20\% different after isoflurane exposure (Cxcl12, Cxcl14, Gata3, Il11, Il13, and Il4ra, for primer sequences see supplementary Table 1). mRNA expression was then measured in cDNA samples of cells exposed to isoflurane and in cells under control conditions. Expression of Cxcl12 was significantly lower under isoflurane exposure $(p=0.023$, Fig. $2 \mathrm{~d})$, whereas no differences were found 
Table 3 Inflammatory Response \& Autoimmunity Array

\begin{tabular}{|c|c|c|c|}
\hline Gene & Description & Gene ID & Function \\
\hline Aft2 & activating transcription factor 2 & 11,909 & Inflammatory Response \& Autoimmunity Gene \\
\hline $\mathrm{Cx} \mathrm{Cl1}$ & chemokine (C-X3-C motif) ligand 1 & 20,312 & $\begin{array}{l}\text { Cytokine Production } \\
\text { Cytokine }\end{array}$ \\
\hline Cxcl12 & chemokine (C-X-C motif) ligand 12 & 20,315 & Cytokine \\
\hline Cxcl14 & chemokine (C-X-C motif) ligand 14 & 57,266 & Cytokine \\
\hline Fadd & Fas (TNFRSF6)-associated via death domain & 14,081 & Inflammatory Response \& Autoimmunity Gene \\
\hline Gata3 & GATA binding protein 3 & 14,462 & Inflammatory Response \& Autoimmunity Gene \\
\hline II10ra & interleukin 10 receptor, alpha & 16,154 & Cytokine Receptor \\
\hline$\| 11$ & interleukin 11 & 16,156 & Cytokine \\
\hline$\| 13$ & interleukin 13 & 16,163 & Cytokine \\
\hline Il13ral & interleukin 13 receptor, alpha 1 & 16,164 & Cytokine Receptor \\
\hline Il17ra & interleukin 17 receptor $\mathrm{A}$ & 16,172 & Cytokine Receptor \\
\hline$\| 18$ & interleukin 18 & 16,173 & Cytokine \\
\hline$\| 4$ ra & interleukin 4 receptor, alpha & 16,190 & Cytokine Receptor \\
\hline Il6ra & interleukin 6 receptor, alpha & 16,194 & $\begin{array}{l}\text { Cytokine Production } \\
\text { Cytokine Receptor }\end{array}$ \\
\hline$\| 6 s t$ & interleukin 6 signal transducer & 16,195 & Cytokine Receptor \\
\hline$\| 7$ & interleukin 7 & 16,196 & Cytokine \\
\hline Inha & inhibin alpha & 16,322 & Inflammatory Response \& Autoimmunity Gene \\
\hline Ltb & lymphotoxin B & 16,994 & $\begin{array}{l}\text { Cytokine Production } \\
\text { Cytokine }\end{array}$ \\
\hline Mif & macrophage migration inhibitory factor & 17,319 & Cytokine \\
\hline Tbck & TBC1 domain containing kinase & 271,981 & Inflammatory Response \& Autoimmunity Gene \\
\hline Tgfb1 & transforming growth factor, beta 1 & 21,803 & Inflammatory Response \& Autoimmunity Gene \\
\hline Tyk2 & tyrosine kinase 2 & 54,721 & Inflammatory Response \& Autoimmunity Gene \\
\hline
\end{tabular}

for the genes Cxcl14, and Gata3 (data not shown). No RT product could be obtained for genes Il11, Il13, and Il14ra.

\section{Discussion}

In our study, we demonstrate wide differences in the gene methylation status between the HT22 cell line and primary hippocampal neurons in the absence of isoflurane exposure, but greater methylation of several genes involved in inflammation upon isoflurane exposure and significant downregulation of Cxcl12 mRNA expression in primary hippocampal neurons. This could represent further epigenetic mechanisms of anesthesia related phenotype in the immature brain. Our results suggest that further studies investigating epigenetic effects of isoflurane or other volatile anesthetics should not be performed on HT22 cells but on primary hippocampal neurons, albeit technically more difficult.

A greater level of methylation was seen in the cell line HT22 than in primary hippocampal neurons. There are only few data on DNA methylation in immortalized cell lines compared to respective primary cells [14-16]. In general, there are cell-type specific methylation signatures preserved in primary cell lines and tissues as well as methylation differences induced by cell culture [16]. For example, the Forkhead box protein L2 promoter is hypermethylated in immortalized but not in primary cells [14]. This argues against a use of HT22 cells to study epigenetic changes, e.g., induced by volatile anesthetics.

In the primary hippocampal neurons, no differences were seen in genes in pathways of cytokine production and apoptosis, but there was a greater methylation of several genes in inflammatory pathways.

Isoflurane anesthesia can evoke neuroinflammation [7] and methylation of genes in the inflammatory pathway may be one molecular mechanism leading to neuroinflammation. Epigenetic mechanisms for isoflurane induced neuroinflammation have already been reported for the aged brain: isoflurane exposure led to declines in chromatin histone acetylation with resulting downregulation of the BDNF- tyrosine kinase receptor B signaling pathway and with increased levels of inflammatory Interleukin 1 beta and Interleukin 6 in aged rats [17]. Our study, therefore, may first indicate that epigenetic modulation of inflammatory genes may also play a role in the 


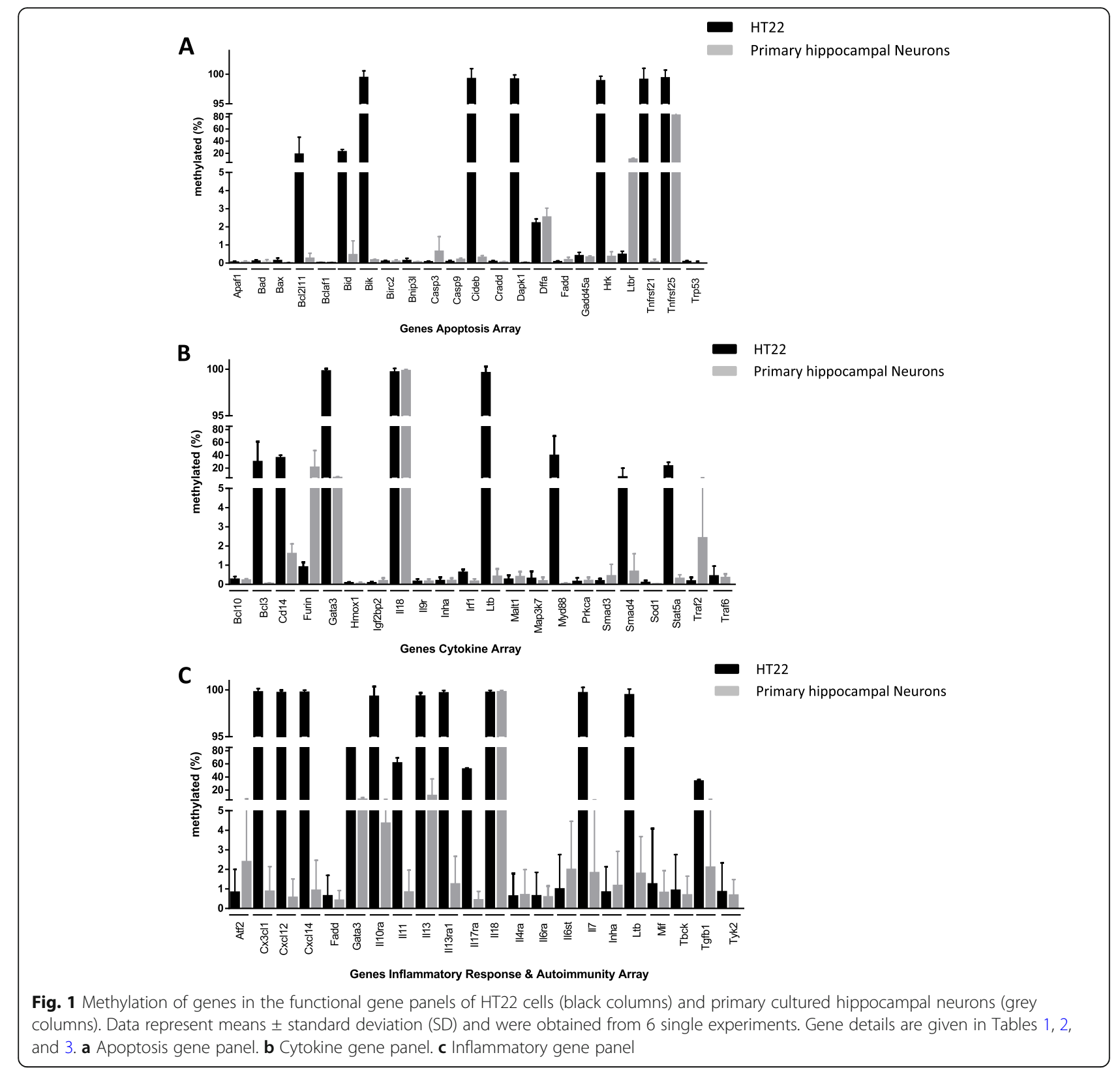

volatile anesthetic induced neuroinflammation in the immature brain and this should be investigated in further studies.

Special regard may be given to the $\mathrm{C}-\mathrm{X}-\mathrm{C}$ motif chemokine 12 (CXCL12), whose mRNA was significantly downregulated, while no differences were found for the genes Cxcl14 and Gata3 and no Real-Time PCR product could be obtained for genes Il11, Il13, and Il14ra. It might be speculated that expression of these genes is too low to become detective.

CXCL12 is a 68-amino-acid CXC chemokine with an essential role in several important processes such as vascular and neuronal development and hematopoiesis [18]. The CXCL12 response takes place at a very early stage of embryonic development and seems to be broadly operative whenever cell migration is required [19]. Mice lacking CXCL12 die prenatally and exhibit defects in vascularization, neuronal development, and hematopoiesis [20]. CXCL12 could be a key chemokine regulating the entrance of lymphocytes into the CNS [21] and immune factors, such as TNF $\alpha$ and interleukins might influence CXCL12 expression [22-25]. In further studies, a promoter characterization of the genes of interest, such as the Cxcl12 promoter, with special regard to the $\mathrm{CpG}$ islands, would be of great importance. The EpiTect Methyl II PCR Array System examines the methylation status across a CpG-rich sequence in gene promoter, however, the exact length of the amplified 


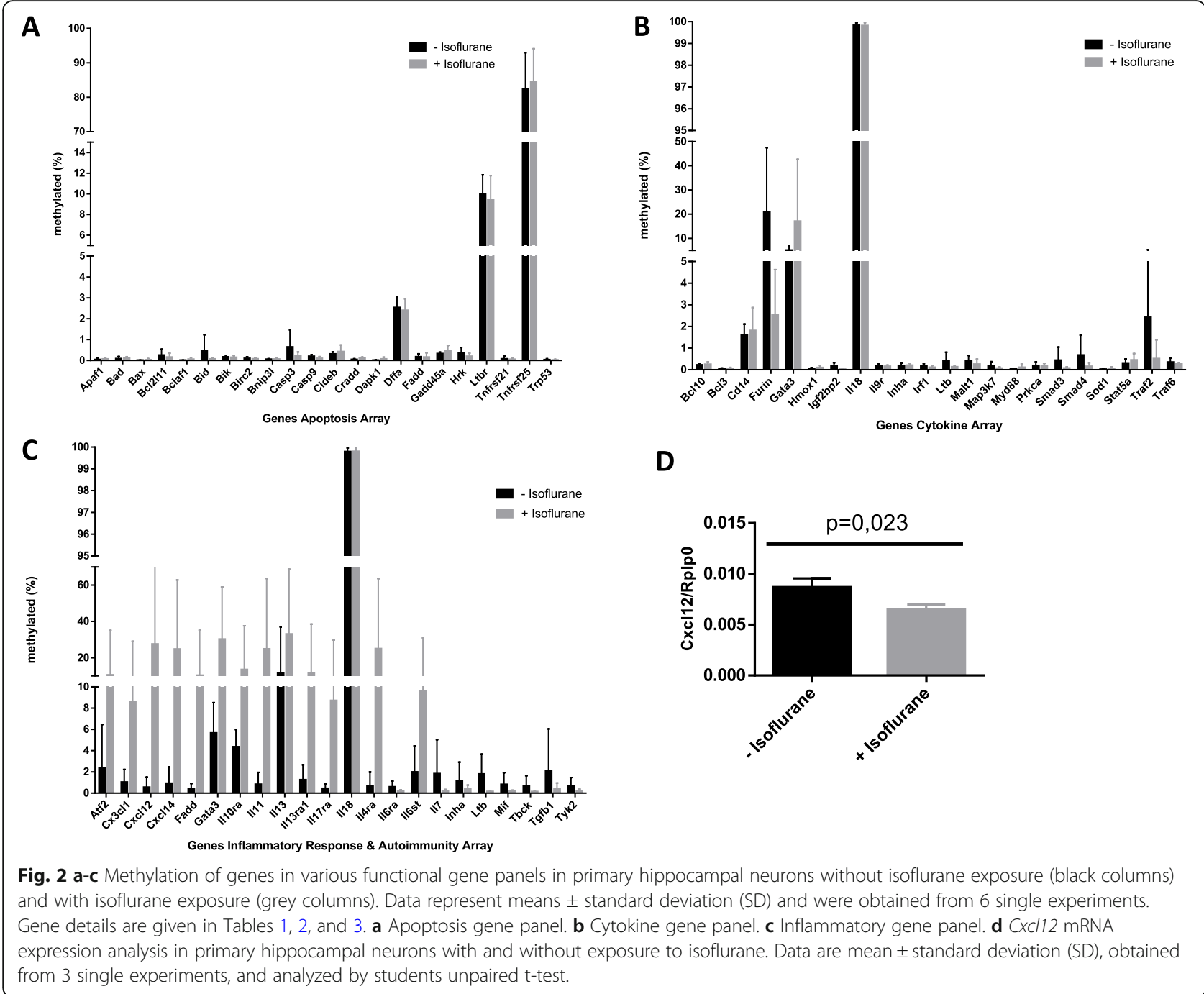

CpG island/promoter and the physical location of the annealing sites of the PCR primers are not disclosed.

Limitations of the study should be mentioned. One important item is the relevant dose and duration of isoflurane administration necessary to evoke DNA methylation changes, if any, and previous data are missing. Previous animal studies are difficult to interpret since long durations and supraanesthetic doses of isoflurane were administered to young animals [26]. While such intense exposures are maybe needed to investigate possible neuropathological and other pathological changes, these conditions hardly relate to human clinical practice. We chose an isoflurane concentration of $3 \mathrm{vol} \%$ inspired but a MAC value cannot be obtained for cell lines. Since the primary hippocampal neurons were exposed to isoflurane on culture days 5, 6, and 7 (mouse hippocampal neurons were isolated from E16-17 mice), therefore, one might speculate that the $3 \%$ isoflurane corresponds to $1 \mathrm{MAC}$ [27], which is a usual clinical dose.
To this end, it also needs to be questioned whether the observed effect of isoflurane is transferable to other volatile anesthetics such as sevoflurane. In a landmark paper, neuroapoptotic properties of equipotent anesthetic concentrations of desflurane, isoflurane, or sevoflurane were compared in neonatal mice and similar neurotoxic profiles were found [27]. However, whether this finding holds true only for only this condition or has to be tested as research hypothesis needs to be clarified.

Furthermore, it needs to be questioned, whether exposure of the primary hippocampal neurons on days 5 , 6 , and 7 was plausible. We believe that this time frame represents a vulnerable phase of brain development. Exposure on three following days was done due to practical and cost reasons, however, analysis of neurons on always the same day may result in different conclusions. Exposure of neurons on three following days may although partly explain the variation of methylation in the 
experiments, which was only seen in the primary hippocampal neurons. It is important to note, that RNA for mRNA expression analysis was obtained from three independent experiments, indicating that our experimental setup was reliable.

For interpreting the results of the EpiTect Methyl II PCR Array System, we considered a methylation change of $>20 \%$ as significant. According to the manufacturer, the significance of the level of methylated DNA must be defined by the researcher. Methylated DNA may have biological significance if such methylation status is associated with a specific phenotype and measuring the corresponding gene expression between samples is recommended. While we did not investigate phenotype changes, we observed significant differences in mRNA expression.

\section{Conclusions}

In conclusion, we demonstrate wide differences in methylation status between HT22 cells and primary cultured hippocampal neurons, with increased methylation in HT22 cells, suggesting that further epigenetic investigations on effects of isoflurane should not be performed in HT22 cells. Furthermore, upon isoflurane exposure in hippocampal neurons we found a greater DNA methylation from several genes involved in inflammation with significant downregulation of Cxcl12 mRNA expression. Based on this a priori analysis, further investigations addressing possible DNA methylation changes in inflammatory genes due to exposure to anesthetics should be performed.

Full name of all genes is given in Tables 1, 2, and 3.

\section{Supplementary information}

Supplementary information accompanies this paper at https://doi.org/10. 1186/s12871-020-00981-4.

Additional file 1.

Additional file 2.

\section{Abbreviations}

BDNF: Brain-derived neurotrophic factor; DNA: Deoxyribonucleic acid; GABA: Gamma-aminobutyric acid; MAC: Minimum alveolar concentration; mRNA: Messenger RNA; NMDA: N-methyl-D-aspartate; RNA: Ribonucleic acid

\section{Acknowledgements}

Not applicable.

\section{Authors' contributions}

Conceived and designed the study and wrote the manuscript: SK, JP, MS. Analysed and interpreted the data: SK, CS, AE, MS. Performed molecular experiments: CS, AE. All authors have read and approved the manuscript.

\section{Funding}

No funding

\section{Availability of data and materials}

The datasets used and/or analyzed during the current study are available from the corresponding author on reasonable request.

\section{Ethics approval and consent to participate}

This study was not submitted to animal institutional ethics committee. Experiments were performed with a permanent cell line (HT22), which was a generous gift from the Salk Institute (La Jolla, CA, USA). The mouse primary hippocampal neurons were commercially obtained from Lonza (Basel, Switzerland) and not produced independently in our laboratory.

Consent for publication

Not applicable.

\section{Competing interests}

The authors declare that they have no competing interests.

Received: 5 July 2019 Accepted: 5 March 2020

Published online: 14 March 2020

\section{References}

1. Pascual M, Do Couto BR, Alfonso-Loeches S, Aguilar MA, Rodriguez-Arias M, Guerri $\mathrm{C}$. Changes in histone acetylation in the prefrontal cortex of ethanolexposed adolescent rats are associated with ethanol-induced place conditioning. Neuropharmacology. 2012;62(7):2309-19.

2. Guo W, Crossey EL, Zhang L, Zucca S, George OL, Valenzuela CF, Zhao X. Alcohol exposure decreases CREB binding protein expression and histone acetylation in the developing cerebellum. PLoS One. 2011;6(5):e19351.

3. Murawski NJ, Klintsova AY, Stanton ME. Neonatal alcohol exposure and the hippocampus in developing male rats: effects on behaviorally induced CA1 c-Fos expression, CA1 pyramidal cell number, and contextual fear conditioning. Neuroscience. 2012;206:89-99.

4. Mori K, lijima N, Higo S, Aikawa S, Matsuo I, Takumi K, Sakamoto A, Ozawa $\mathrm{H}$. Epigenetic suppression of mouse Per2 expression in the suprachiasmatic nucleus by the inhalational anesthetic, sevoflurane. PLoS One. 2014;9(1): e87319.

5. Dalla Massara L, Osuru HP, Oklopcic A, Milanovic D, Joksimovic SM, Caputo V, DiGruccio MR, Ori C, Wang G, Todorovic SM, et al. General anesthesia causes epigenetic histone modulation of c-Fos and brain-derived Neurotrophic factor, target genes important for neuronal development in the immature rat Hippocampus. Anesthesiology. 2016;124(6):1311-27.

6. Ju LS, Jia M, Sun J, Sun XR, Zhang H, Ji MH, Yang JJ, Wang ZY. Hypermethylation of hippocampal synaptic plasticity-related genes is involved in neonatal Sevoflurane exposure-induced cognitive impairments in rats. Neurotox Res. 2016;29(2):243-55.

7. Shen X, Dong Y, Xu Z, Wang H, Miao C, Soriano SG, Sun D, Baxter MG, Zhang $Y$, Xie Z. Selective anesthesia-induced neuroinflammation in developing mouse brain and cognitive impairment. Anesthesiology. 2013; 118(3):502-15.

8. Lee BH, Chan JT, Hazarika O, Vutskits L, Sall JW. Early exposure to volatile anesthetics impairs long-term associative learning and recognition memory PLoS One. 2014:9(8):e105340.

9. Jevtovic-Todorovic V, Hartman RE, Izumi Y, Benshoff ND, Dikranian K, Zorumski CF, Olney JW, Wozniak DF. Early exposure to common anesthetic agents causes widespread neurodegeneration in the developing rat brain and persistent learning deficits. J Neurosci. 2003;23(3):876-82.

10. Fredriksson A, Ponten E, Gordh T, Eriksson P. Neonatal exposure to a combination of N-methyl-D-aspartate and gamma-aminobutyric acid type a receptor anesthetic agents potentiates apoptotic neurodegeneration and persistent behavioral deficits. Anesthesiology. 2007;107(3):427-36.

11. Klenke S, Renckhoff K, Engler A, Peters J, Frey UH. Easy-to-use strategy for reference gene selection in quantitative real-time PCR experiments. Naunyn Schmiedeberg's Arch Pharmacol. 2016;389(12):1353-66.

12. Karatzas PS, Mantzaris GJ, Safioleas M, Gazouli M. DNA methylation profile of genes involved in inflammation and autoimmunity in inflammatory bowel disease. Medicine (Baltimore). 2014;93(28):e309.

13. Pereira NB, ACM DC, Campos K, Costa S, Diniz MG, Gomez RS, Gomes CC. DNA methylation polymerase chain reaction (PCR) array of apoptosis-related genes in pleomorphic adenomas of the salivary glands. Oral Surg Oral Med Oral Pathol Oral Radiol. 2017;124(6):554-60.

14. Tran S, Wang Y, Lamba P, Zhou X, Boehm U, Bernard DJ. The CpG island in the murine foxl2 proximal promoter is differentially methylated in primary and immortalized cells. PLoS One. 2013;8(10):e76642.

15. Smiraglia DJ, Rush L, Fruhwald MC, Dai Z, Held WA, Costello JF, Lang JC, Eng C, Li B, Wright FA, et al. Excessive CpG island hypermethylation in 
cancer cell lines versus primary human malignancies. Hum Mol Genet. 2001; 10(13):1413-9.

16. Varley KE, Gertz J, Bowling KM, Parker SL, Reddy TE, Pauli-Behn F, Cross MK, Williams BA, Stamatoyannopoulos JA, Crawford GE, et al. Dynamic DNA methylation across diverse human cell lines and tissues. Genome Res. 2013; 23(3):555-67.

17. Ji M, Dong L, Jia M, Liu W, Zhang M, Ju L, Yang J, Xie Z, Yang J. Epigenetic enhancement of brain-derived neurotrophic factor signaling pathway improves cognitive impairments induced by isoflurane exposure in aged rats. Mol Neurobiol. 2014;50(3):937-44.

18. Momcilovic M, Mostarica-Stojkovic M, Miljkovic D. CXCL12 in control of neuroinflammation. Immunol Res. 2012;52(1-2):53-63.

19. Nagasawa T, Nakajima T, Tachibana K, lizasa H, Bleul CC, Yoshie O, Matsushima K, Yoshida N, Springer TA, Kishimoto T. Molecular cloning and characterization of a murine pre-B-cell growth-stimulating factor/stromal cell-derived factor 1 receptor, a murine homolog of the human immunodeficiency virus 1 entry coreceptor fusin. Proc Natl Acad Sci U S A. 1996;93(25):14726-9

20. Zou YR, Kottmann AH, Kuroda M, Taniuchi I, Littman DR. Function of the chemokine receptor CXCR4 in haematopoiesis and in cerebellar development. Nature. 1998;393(6685):595-9.

21. Prendergast $\mathrm{CT}$, Anderton $\mathrm{SM}$. Immune cell entry to central nervous system--current understanding and prospective therapeutic targets. Endocr Metab Immune Disord Drug Targets. 2009:9(4):315-27.

22. Chung IY, Norris JG, Benveniste EN. Differential tumor necrosis factor alpha expression by astrocytes from experimental allergic encephalomyelitissusceptible and -resistant rat strains. J Exp Med. 1991;173(4):801-11.

23. Constantinescu CS, Hilliard B, Ventura E, Wysocka M, Showe L, Lavi E, Fujioka T, Scott P, Trinchieri G, Rostami A. Modulation of susceptibility and resistance to an autoimmune model of multiple sclerosis in prototypically susceptible and resistant strains by neutralization of interleukin-12 and interleukin-4, respectively. Clin Immunol. 2001;98(1):23-30.

24. Cautain B, Damoiseaux J, Bernard I, van Straaten H, van Breda VP, Boneu B, Druet $P$, Saoudi A. Essential role of TGF-beta in the natural resistance to experimental allergic encephalomyelitis in rats. Eur J Immunol. 2001;31(4): 1132-40.

25. Segal BM, Dwyer BK, Shevach EM. An interleukin (IL)-10/L-12 immunoregulatory circuit controls susceptibility to autoimmune disease. $J$ Exp Med. 1998:187(4):537-46.

26. Hansen TG, Lonnqvist PA. The rise and fall of anaesthesia-related neurotoxicity and the immature developing human brain. Acta Anaesthesiol Scand. 2016;60(3):280-3.

27. Istaphanous GK, Howard J, Nan X, Hughes EA, McCann JC, McAuliffe JJ, Danzer SC, Loepke AW. Comparison of the neuroapoptotic properties of equipotent anesthetic concentrations of desflurane, isoflurane, or sevoflurane in neonatal mice. Anesthesiology. 2011;114(3):578-87.

\section{Publisher's Note}

Springer Nature remains neutral with regard to jurisdictional claims in published maps and institutional affiliations.

Ready to submit your research? Choose BMC and benefit from:

- fast, convenient online submission

- thorough peer review by experienced researchers in your field

- rapid publication on acceptance

- support for research data, including large and complex data types

- gold Open Access which fosters wider collaboration and increased citations

- maximum visibility for your research: over $100 \mathrm{M}$ website views per year

At $\mathrm{BMC}$, research is always in progress.

Learn more biomedcentral.com/submissions 